\title{
THE ROLE OF INSTITUTIONS IN REGIONAL DEVELOPMENT
}

Janis Ezers ${ }^{1}$, MBA; Kaspars Naglis-Liepa ${ }^{1}$, Dr.oec., assistant professor

${ }^{1}$ Latvia University of Life Sciences and Technologies, Faculty of Economics and Social Development

\begin{abstract}
Regional disparities have been a focus of scientific discussions for more than a century. Today, economic growth or development factors are as much important as, for example, sustainable development factors in the environmental and social dimensions. Social equality and public participation in state and environmental governance - through regional institutional cooperation - are among the priorities of sustainable development. Research on institutional cooperation is an urgent priority. Previous research studies indicated that local governments in the regions of Latvia implemented isolationistic policies both at the horizontal and at the vertical level, which was promoted by their competition aimed at benefiting themselves, ignoring common public interests. Previous cooperation among regional institutions was fragmented and based on short-term economic interests. The research aim is to assess the role of institutional cooperation, placing a special focus on research done by national economists. After performing a literature review, the authors concluded that the research papers of both foreign and national researchers have stressed the essential role of institutional cooperation in regional economic development. Further and more detailed research has to be done on the pace of territorial growth, depending on local and national institutional cooperation.
\end{abstract}

Key words: new institutional economics, regional development, cooperation, collaboration. JEL code: H79, I25, O38, R11.

\section{Introduction}

Successful (unsuccessful) institutional cooperation at the regional, national and international levels affect regional development. The role of institutions in regional development in Latvia has been researched, yet the aspect of institutional cooperation as an instrument for economic growth has to be researched more extensively. A considerable part of the mentioned research focused on reducing the administrative burden (Upite I., Pilvere I., Nipers A., 2011; et al.), cooperation among municipalities in Latvia (Bite D., 2012), cooperation among nongovernmental organisations (Razma N., 2013; et al.) as well as institutional effects on socio-economic development (Vitola A., 2016). Growth factors in the regions, the choice of public policies and potential development models (Kalnina-Lukasevica Z., 2013) as well as the urban system in Latvia and the prospects for it have been researched as well (Zaluksne V., 2014). Institutional cooperation in the regions of Latvia has been insufficiently researched at the academic level, while any research study on this field referred to the need to improve the institutional cooperation in particular. Most often, any analysis of institutional cooperation models refers to best practices to be taken over from foreign twin cities or formal measures prescribed by the government. There is a lack of comprehensive studies on institutional cooperation practices in cities under state jurisdiction and scientifically substantiated recommendations for improving the cooperation models. The research aim is to assess the role of institutional cooperation, placing a special focus on research done by national economists. The research analysed the scientific literature, policy documents and the relevant legal framework.

F.Hindriks and F.Guala point out that institutions are present everywhere - even writing their research paper entitled Institutions, Rules, and Equilibria: a Unified Theory, the authors had to indicate their position - professors - and workplaces - universities etc., namely their institutional affiliation (Hindriks F., Guala F., 2015). New institutional economics states that particularly institutions are those whose formal (legal framework) and informal (undefined yet existing rules) mechanisms represent the reason of economic disparities across nations. In his General Theory of

\footnotetext{
${ }^{1}$ Contacts to be added to the author, as a footnote at the bottom of the first page ( 6 point Verdana font)
} 
Employment, Interest and Money, British economist John Meynard Keynes stressed the role of the government in economic development as well as pointed out that it is important to comprehend the economic principles under which the society live (Keynes, 1936).

\section{Research results and discussion}

Institutional cooperation at the horizontal and at the vertical level is a research problem for regional economics in Latvia; for example, this problem has to be researched by conducting an expert survey, a focus group survey or processing statistical data. To date, the roles of local or national governments in the economic development of the regions as well as institutional socio-economic effects have been a research problem. For this reason, focusing on institutional cooperation effects on economic processes is currently urgent in Latvia.

Pranab Bardhan points out that institutional economics is a topical field in economic science, as the key difference between wealthy and poor nations, perhaps, lies in the institutional system in particular in the countries (Bardhan P., 2010). A considerable contribution to institutional economics has been made by a US economist, Nobel peace prize winner (1993) Douglass North. D.North has pointed out that individuals have established institutions to create order and reduce uncertainty in economic activity, as well as the fact that the institutions are those shaping the economic structure promoting or hindering growth, including ownership, the tax system, fiscal and monetary policies (North D., 1991). Collecting qualitative data on institutions, Aljaz Kuncic, an economist at Ljubljana University, has classified institutions into three categories: legal, political and economic. He made a set of data on 197 countries, for the period from 1990 to 2010. The data allow identifying whether the government improves the institutional framework and whether it might be done in a better way. It is important to assess the extent to which a country develops its institutional framework to achieve economic growth; accordingly, relevant criteria have to be selected. A.Kuncic points out that institutional quality, including cooperation, is associated with geographical division - the highest quality is reported in North America, Japan, Central and Northern Europe, as well as a positive correlation is found between institutional characteristics and economic indicators (e.g. GDP per capita). Making considerable efforts, the researcher managed to make a data set for a period of 21 years and for more than 100 countries, which allows tracing the dynamics of the institutional framework as well as enables other researches and institutions to use it (Kuncic A., 2014).

The White Paper on European governance (2001), which was adopted on 25 July 2001, refers to five principles - openness, participation, accountability, effectiveness and coherence - as those of best governance. Out of the five principles, at least three directly underpin the significance of institutional cooperation: openness - institutions have to be more open and actively communicate among one another; participation - the effectiveness of institutions is directly dependent on how successful is the participation of the other ones; coherence - cooperation among regional institutions have to be coordinated. Of course, the other two principles referred to in the White Paper on European governance - accountability and effectiveness - also represent the basis of good cooperation.

At the national level, a good example of cooperation among national and regional institutions and entrepreneurs is the support programme of the Cohesion Fund, administered by the Ministry of Environmental Protection and Regional Development, for entrepreneurship in municipalities in the period 2014-2020. The purpose of it is to foster entrepreneurship and revitalise brownfield areas so that the areas belonging to local governments are redeveloped and entrepreneurship centres are established in the planning regions of Latvia. 
Institutional cooperation could be viewed as an opposite of competition. Competition is perceived as a struggle, a race for someone to win and someone to lose, whereas cooperation arises from another paradigm - any institution exists in the same space where overall development, a boom could be achieved based on cooperation. Development is promoted by cooperation, taking into account the strengths and weaknesses of the region, as well as the opportunities and threats and contributing to the economic pattern characteristic of the region and innovation - scientific, technological, economic and other ideas - that result in developing new goods or services and making them available on the market. In his voluminous work An Inquiry into the Nature and Causes of the Wealth of Nation, the founder of classical economic thought, Adam Smith, has stressed that the highest motive for the activity of individuals is their egoism and the wish to benefit themselves. It is likely that A.Smith made this finding based on his own experience, as in his previous work entitled the Theory of Moral Sentiments he referred to individuals as ethical and moral beings. One could understand that egoism as a prudent care about one's own benefit could be seen a positive until it begins restricting another individual's right to freedom and reasonable benefits. Of course, A.Smith pointed out that by seeking to satisfy one's own needs, every member of society also benefits the society as a whole (Smith A., 1776).

The present research views cooperation from the win-win perspective defined by S.Covey - both (or all) institutions involved are winners in the result of their cooperation rather than some of the parties gains, whereas another one loses or all the parties lose. According to S.Covey, who is an internationally recognised authority on leadership and an advisor to organisations on strategies, the win-win situation or mutual benefit means that an agreement or solution is mutually beneficial (for everyone) and satisfies both (all) parties involved. Owing to mutual benefit, all the parties involved feel satisfied and associated through a jointly accepted plan of action. Mutual benefit is the third alternative. It is not the path of one or another party; it is the best possible path (Covey R.S., 1989). It is important to use the win-win principle, which is the basis of successful cooperation, in cooperation among institutions in order to contribute to economic development in the regions.

To observe economic principles, economic activities have to be innovative, competitive and resource-efficient; it could be achieved if effective institutional cooperation is implemented. A lack of cooperation, including communication, is often the cause of an unfavourable entrepreneurial environment in municipalities. Researching economic transformation processes and results in Kurzeme region, K.Kreslins and his colleagues have found that regional institutions have to change their dominant "residential district mentality" that has emerged owing to the tax system imposed at the national level - the key source of tax revenues for local governments is the individual income tax, which urges them to compete for residents to be declared in their administrative territories. It is important to create an institutional framework that contributes to knowledge-based entrepreneurship and motivates businesses to invest in education and science. The researchers point out that it is important to establish networks of cooperation among universities as knowledge creators, business incubators as institutions conducive to entrepreneurship and entrepreneurs being ready to implement new ideas in practice, thereby contributing to the development of the regions. A considerable share of the researchers' conclusions refer to the need to continue cooperation among various institutions as well as make targeted investments in education and science, which contributes to the creation of new knowledge-intensive jobs in the region. As an excellent example of institutional cooperation, the researchers suggest establishing clusters representing a network of independent organisations comprised of enterprises and institutions creating knowledge (innovations) (i.e. 
universities, research centres) and national and municipality-level institutions. The establishment of clusters would ensure the transfer of knowledge and skills as well as cooperation and the implementation of common interests (Kreslins K., et al., 2018).

Effective and fruitful cooperation emerges among institutions if it is shaped according to a scheme presented in Figure 1.

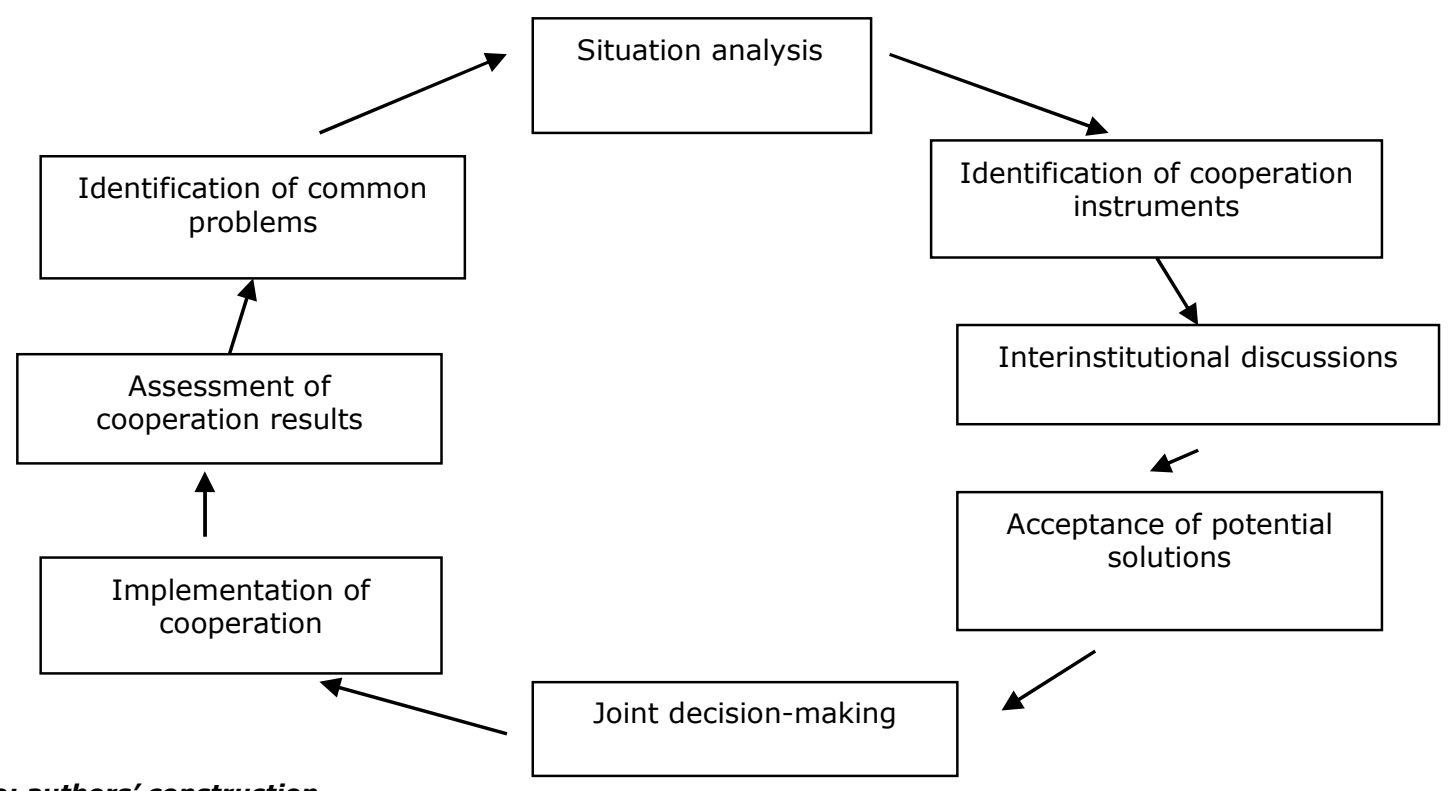

Source: authors' construction

Fig. 1. Schematic representation of institutional cooperation

Institutional cooperation is a non-stop process; it is meaningful if the planned outcome or even a better outcome is achieved. If the planned outcome, or even a better one, is not achieved, the institutions have to continue working on the solution to the problem. According to the scheme of institutional cooperation, the process of cooperation begins when the institutions identify a common problem. As long as No common problem has been identified, institutional cooperation is not necessary. Accordingly, the first essential step to be made is the identification/definition/determination of a common problem. After the common problem has been identified - institutions perform a situation analysis; depending on the nature of the problem, the analysis could be either detailed or simple. Based on the situation analysis, institutions determine cooperation instruments and carry out interinstitutional discussions on potential solutions and making the common final decision, which is based on the win-win principle making all the parties involved beneficiaries, so that none of the institutions is a loser or "sacrificed" in the result of cooperation. Only after the win-win decision has been made, institutions implement cooperation aimed at achieving the outcome; during the cooperation, an interim assessment of the outcome is made as well. Only if it is a win-win outcome, one can consider the goal has been achieved. If the win-win outcome has not been achieved, institutions continue tackling the problem until the win-win outcome is achieved or the planned outcome is changed/corrected.

To achieve a win-win outcome, institutional cooperation has to be both vertical, e.g. implemented on an international/national/regional scale, which is based on a uniform/similar legal framework throughout the European Union, and horizontal. It is essential that the employees of organisations are focused on achieving synergy, trust and cooperation, allow different views while cooperating and possess other important traits needed for cooperation. This paper section is essential for institutional cooperation, yet in more detail it is not discussed further. 
Researching the knowledge-based economy in Vidzeme region, G.Krumins and his colleagues point to a positive fact that the region has the Valmiera Business Incubator and the Madona Business Incubator, Vidzeme University of Applied Sciences and other educational institutions providing support to entrepreneurs and therefore a competitive advantage, e.g. in designing business plans (Krumins G. et al., 2018). In surveys conducted by the researchers, entrepreneurs pointed out that mostly those who graduated from a particular educational institution were engaged in cooperation with the institution; accordingly, based on the surveys one can conclude that, first, the fact that an educational institution is located in the region or municipality could be regarded as a competitive advantage; second, both the educational institution and the entrepreneurs who have not graduated from it have to be ready to cooperate in order to develop their businesses. For example, just like the business incubators, Vidzeme University of Applied Sciences offers new entrepreneurs bureaus in some of its rooms and Internet connection. In the mentioned surveys, the chairman of the Cesis Council has pointed out that cooperation with educational institutions is useful because "if our schools teach the basics of computer programming, the relevant human resources will be available. If a specialist can have a job, s/he is interested in staying in the municipality". In the mentioned research, Cesis was analysed as a good example shoving that regional institutions have to cooperate not only with regional educational institutions but also with a national-level university - Riga Technical University. As national-level institutions, business incubators effectively provide support to new entrepreneurs through giving them bureaus, advice and funds. As solutions to the development of human resources in Vidzeme region, the researchers recommend municipality institutions to cooperate with nongovernmental and private institutions in order to tackle problems caused by migration, establish a cooperation network with the educational and research institutions of the region in order to stimulate innovation in entrepreneurship and contribute to communication, thereby giving way to private initiatives (Krumins G. et al., 2018). An analysis of the mentioned research on the knowledge-based economy in rural areas allows concluding that business incubators are one of the most successful examples how to shape cooperation among various institutions - the European Union (ERDF), national institutions (Investment and Development Agency of Latvia (IDAL)), a local government and new entrepreneurs. Cooperation occurs among political (EU), legal (IDAL, local government) and economic institutions. The authors (Krumins G. et al., 2018) believe that this is a good example of successful cooperation that indicates that institutional cooperation leads to a real improvement in economic indicators - new enterprises are started up, new jobs are created, unemployment declines and GDP per capita in the region increases.

After researching economic growth problems in Zemgale region, B.Rivza, M.Kruzmetra, A.Zvirbule and Z.Vitolina suggest expanding cooperation among scientific and practice institutions, administrative institutions and the population, as well as cooperation among the residents themselves as a priority for contributing to the knowledge-based economy. A positive example is the Department for Technology and Knowledge Transfer of Latvia University of Life Sciences and Technologies; the purpose of it is to contribute to the commercialisation of scientific innovations. Owing to cooperation with entrepreneurs, innovative products such as baby foods under the brand Rudolfs, cereals MILZU, dietetic foods produced from natural raw materials for people with health problems, chewing beebread pastilles, vegeTable products and many other products have been created. The researchers point out that in Zemgale region, institutional information exchange among local governments and entrepreneurs is developed well within the e-environment. In cooperation among the Jelgava Entrepreneur Association (nongovernmental organisation), the Latvian Chamber 
of Commerce and Industry (nongovernmental organisation) and the Jelgava Business Incubator of the Investment and Development Agency of Latvia (governmental institution), a series of activities "Business Club" are held to contribute to professional competences of entrepreneurs, sharing experience and a good environment for communication among entrepreneurs. Even though there are good examples of institutional cooperation in Zemgale region, further progress in the knowledge economy requires, first, more cooperation between local governments and local residents - a focus has to be put on jointly defining the goals to be achieved and the specific tasks to be performed by (local governmental and nongovernmental) institutions to achieve the goals. Not a less important priority is how to make entrepreneurs associate so that they share their knowledge, skills and experience, thereby contributing to the entrepreneurial environment in the regions. The population too should be more involved in nongovernmental organisations, the purpose of which would be to contribute to the knowledge economy in the regions (Rivza B. et al., 2018).

I.Jundrupa and M.Senfelde, conducting a research study on competitiveness in the planning regions of Latvia, suggest establishing an institution being trusted by all the stakeholders and responsible for cooperation and setting common goals and holding interinstitutional meetings etc. (Jundrupa I. et al., 2011). At the national level, the Cross-Sectoral Coordination Centre has been established that, in accordance with its Statute, is the leading national development planning institution. In cooperation with other national institutions, it designs national-level policy documents as well as provides interinstitutional cooperation and joint action for common national goals. A separate research study should be done on the performance of the Cross-Sectoral Coordination Centre in relation to its responsibility for cooperation and coordination.

After getting familiarised with the research studies in regional economics by national scientists, one can conclude that in the regions where regional universities or research centres are located, local institutions demonstrate more initiatives, cooperating with municipality institutions, research institutions and entrepreneurs, thereby promoting innovation in the region. Good examples of institutions contributing to a favourable environment for development and innovation are as follows: Vidzeme University of Applied Sciences, Ventspils University College, Liepaja University, Latvia University of Life Sciences and Technologies, Daugavpils University and Rezekne Academy of Technologies. Of course, it is essential that the national legal framework contributes to an environment conducive to cooperation among various institutions, thereby fostering economic growth. An analysis of the research studies on regional development in Latvia by national scientists allows concluding that in order to promote cooperation among regional institutions in the regions of Latvia, it is important to:

1) create a national and municipal legal framework conducive to cooperation among regional institutions aimed at introducing innovations rather than competition with one another;

2) design a regional strategy for a particular municipality to cooperate among local institutions and introduce innovations;

3) provide national institution support (financial and nonfinancial instruments) for cooperation among local institutions with the aim of introducing innovations;

4) promote cooperation among national and regional institutions aimed at introducing innovations.

\section{Conclusions, proposals, recommendations}

1) The scientific literature review allows concluding that institutions represent a behaviour accepted in society that has developed over a long period. It is required to distinguish the formal 
(institutions) - the legal framework - from the informal - the dominant views, values and standard behaviour of a particular society that are not regulated by a legal framework but are observed by the society them because "it is acceptable" in the society.

2 ) In the regions of Latvia, institutions are often insufficiently oriented towards cooperation and mainly make isolationistic policies that hinder the development of the region in a long-term.

3) Innovative enterprises generating higher value-added goods and services are mainly established in the regions of Latvia where universities and research centres are located and effectively perform as well as institutions oriented towards cooperation are available.

\section{Bibliography}

1. Bardhan, p. (2010). Institutional Economics of Development: Some General Reflections. Institutional Microeconomics of Development. , MIT Press, 2010.

2. Bite, D. (2012). Cooperation of Local Governments in Latvia". Riga 2012.

3. Covey, R.S. (1989). The 7 Habits of Highly Effective people.

4. Hindriks, F., Guala, F. (2015). Institutions, Rules, and Equilibria: a Unified Theory. Journal of Institutional Economics (2015), 11:3, 459-480.

5. Jundrupa, I., Senfelde, M. (2011). Konkuretspejas novertesana Latvijas planosanas regionos (Competitiveness Assessment in the Planning Regions of Latvia). Scientific Journal of Riga Technical University, Economics and Business. Economy.

6. Kalnina-Lukasevica, Z. (2013). Development of Regions in Latvia - the Model of Regional Economic Development, Planning and Evaluation. Riga. University of Latvia.

7. Keynes, J.M. (1936). The General Theory of Employment, Interest and Money. https://www.marxists.org/reference/subject/economics/keynes/general-theory/index.htm

8. Kreslins, K., Libkovska, U., Sunina, L., Stefenberga, D. (2018). Tautsaimniecibas transformacijas procesi un rezultati Latvijas regionos. Kurzemes regions. Zinasanu ekonomika Latvijas lauku un regionu dzivotspejai (Economic Transformation Processes in the Regions of Latvia. Kurzeme Region. The Knowledge Economy for the Viability of Rural Areas and Regions of Latvia). pp. 51-72.

9. Krumins, G., Rozentale, S., Melbarde, V., Ore, M., Andersons, A., Eglitis, R. (2018). Tautsaimniecibas transformacijas procesi un rezultati Latvijas regionos. Kurzemes regions. Zinasanu ekonomika Latvijas lauku un regionu dzivotspejai (Economic Transformation Processes in the Regions of Latvia. Kurzeme Region. The Knowledge Economy for the Viability of Rural Areas and Regions of Latvia). pp. 160-228.

10. Kuncic, A. (2014). Institutional Quality Dataset. Journal of Institutional Economics (2014), 10, pp. 135-161.

11. North, D.C. (1991). Institutions. Journal of Economic Perspectives - Volume 5, Number I-Winter 1991, pp.97-112.

12. Razma, N. (2013). Nevalstisko organizaciju darbibas arvalstu prakses izpete un sadarbibas modela izstrade. Priekules novads (Examination of Foreign Practices of Nongovernmental Organisations and the Development of a Model for Cooperation. Priekule Municipality).

13. Rivza, B., Kruzmetra, M., Zvirbule, A., Vitolina, Z., Tautsaimniecibas transformacijas procesi un rezultati Latvijas regionos. Zemgales regions. Zinasanu ekonomika Latvijas lauku un regionu dzivotspejai (Economic Transformation Processes in the Regions of Latvia. Zemgale Region. The Knowledge Economy for the Viability of Rural Areas and Regions of Latvia). pp. 228-282.

14.Smith, A. (1776). An Inquiry into the Nature and Causes of the Wealth of Nations. https://www.ibiblio.org/ml/libri/s/SmithA_WealthNations_p.pdf

15. The White Paper "European Governance". Brussels. 25.07.2001.

16. Upite, I., Pilvere, I., Nipers, A., (2011). Economic Evaluation of Administrative Burden for Construction in Jelgava Municipality. International Journal of Economics and Finance Studies. Vol 3, No.2, 2011.

17. Vitola, A. (2016). An Evaluation of the Socioeconomic Impact of Institutions. RTU Publishing House.

18.Zaluksne, V., (2014). The Urban System in Latvia and its Development Prospects. Jelgava. 